\title{
The Role of Administrative Trading in Job Destructive Reflections: with the Mediating Role of Employees' Political Behavior
}

Aleme Keikha ${ }^{1}$ Assistant Professor, University of Sistan and Baluchestan, Zahedan, Iran. (Corresponding Author)

Iman Shahbakhsh Ghalami M.A. in Public Administration, Islamic Azad University, Zahedan Branch, Zahedan, Iran.

\begin{abstract}
Job destructive reflections impose heavy costs on organizations and employees. Considering these negative consequences and their effects on employee performance and organizations' productivity, the purpose of this study is to investigate the role of administrative trading in the destructive reflections of job with the mediating role of political behavior among Zahedan Municipality employees. Data were collected from 300 employees and structural equations modeling approach was applied for data analysis. Results show that administrative trading, consisting of indexes such as acquiring higher status, work processes and financial resources have positive and significant impact on job destructive reflections, consisting of such indexes as job disinterest, job stress and organizational cynicism. Moreover, political behavior consisting of social awareness, interpersonal influence, network capability and honesty has positive and significant impact on job destructive reflections, and in the relation between administrative trading and job destructive reflections, it has negative mediating effect.
\end{abstract}

Keywords: Administrative Trading, Job-destructive Reflections, Political Behavior, Zahedan Municipality, Structural Equation Modeling. 


\section{مقدمه}

سوداگرى يكى از يديدههاى جهانى است كه از ديرباز با ييدايش شكلهاى اوليه حكومت وجود داشته و عاملى مهرم در ايجاد آسيب به سياستها و منافع عمومى سازمانها بوده است (عظيمى و همكاران، (وسا). اين امر يك مسئله فراگير است كه مىتواند همه دستخاههاى ادارى يكى كشور را درگير كند و ييامدهايى در قالب سوء استفاده از موقعيتهاى شغلى، ارتشا، و اختلاس ايجاد

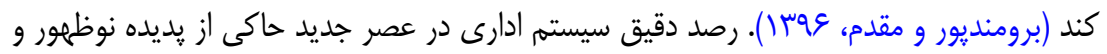
خزندهاى به نام سوداگرى ادارى است كه با آثار مخربتر و عميقتر، و در عين حال ناملموستر، اصالت و سلامت اداره سازمانها را تهديد مى كند. يديدهاى كه موجب مى شود منصبها، سِمتها، و جايگاههاى سازمانى ابزارى براى جِياول بيتالمال، ارتقاى سمت مديران و كاركنان، و كسب

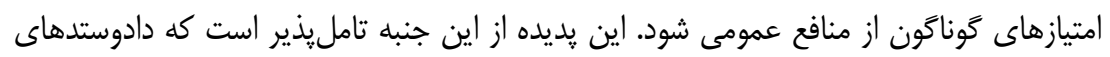
صورت گرفته ميان افراد گوناگون فقط به صورت اعطاى يول و كسب امتياز نيست، و مهمرتر اين كه با بررسى بخشى از ارتباطات متقابل افراد كشف نمىشود و براى كشف آن بايد زنجيرهاى از ارتباطات، جرخه تبادل قدرت، امتياز، و جايگاه سازمانى بررسى شود (Vinzi et al., 2010). وجود اين يديده

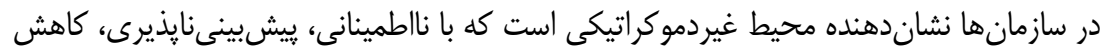
ارزشهاى اخلاقى، و بىاحترامى به نهادها و قدرتهاى قانون اساسى همراه است و به تهريد امنيت انسانى و منابع اقتصادى و سياسى منجر مى گردد و سازوكارهاى قضايى را تحت شعاع

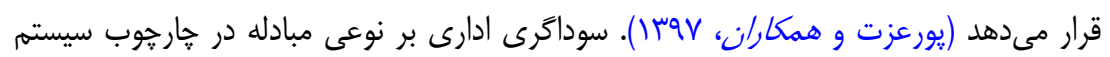
ادارى دلالت دارد كه منافع عمومى را متاثر مى كند و آنجه طرفين را به اين مبادله قادر مىسازده، قدرتى است كه به سبب جايگاه سازمانى ايجاد مىشود؛ در حالى كه اين جايگاه امانتى از حوزه عمومى جامعه است. اگر دستكم يكى از طرفين شرايط بالا را داشته باشند، سوداگرى تحقق مىيابد (ربيعى و آصف، (وس ). از طرفى، در عصر حاضر توجه به رفتارهاى مضمحل كننده شغلى براى سازمانها اهميت ويزهاى دارد، زيرا ايدهها و نظرهاى كاركنان مىتواند راهگشاى بسيارى ازئ مشكلات سازمانى و همزمان منعكس كننده علايق و خواستههاى آنها به مديريت سازمان باشد

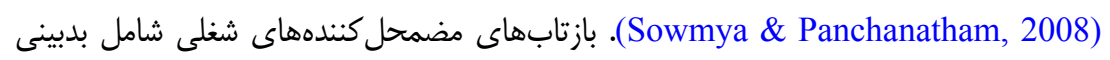
سازمانى، كارزدگى، و تنيدگى در كاركنان است (موذن جمشيدى و حقيرست كنارسرى، Vوسا). 
وجود بازتابهاى مضمحل كنندة شغلى با اثركذارى منفى بر سلامت سازمان موجب كاهش نرخ

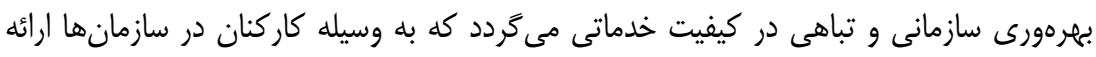
مىشود (شريفزاده و همكاران، ع بوسا). بحرانهاى سياسى و اقتصادى، كميابى منابع، وابستخى منابع، نفوذ افرادى كه در كذشته در

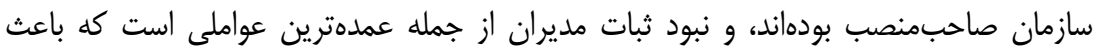

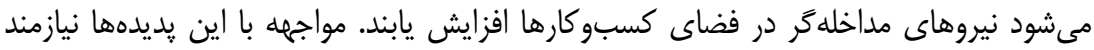

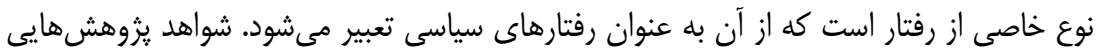

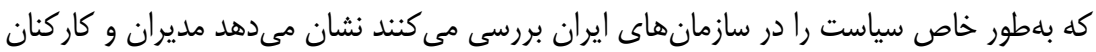
ايرانى، نهتنها نخرش مثبتى نسبت به طرح مباحثى جون قدرت و سياست در سازمان ندارند، بلكه

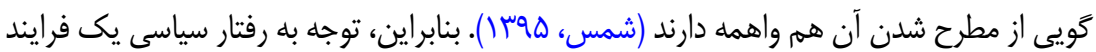

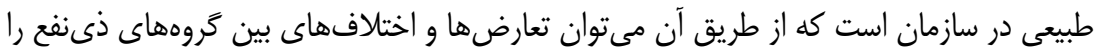

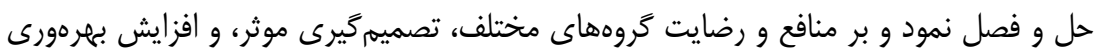

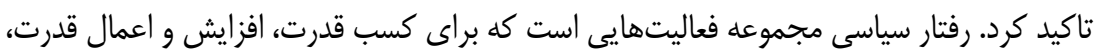

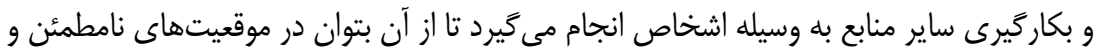

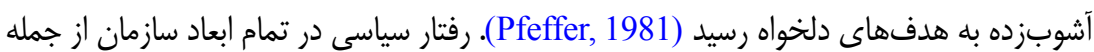
حلوفصل تعارضها و تصميمَّيرى اثر مى كذارد. در شهردارى زاهدان نيز همانند بسيارى از شهرهاى ديخر و حتى جهان، مساردئ مسئله بروز رفتارهاى

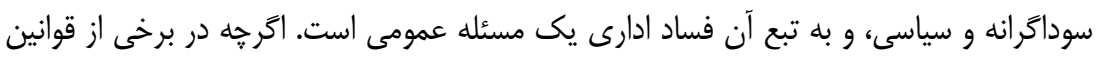

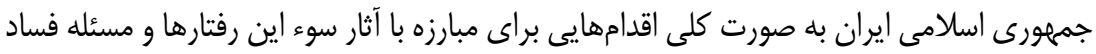
و ارتقاى سطح سلامت ادارى در سطوح مختلف سازمانى و جامعه شده است و در دايره دستخاههاى

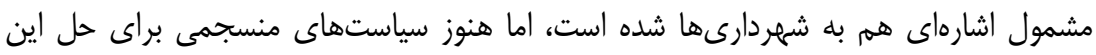
مشكل در سطح شهردارىها، بلوويزه شهردارى زاهدان، تدوين نشده است. يّ تدوين سياستهاى

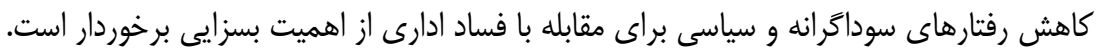

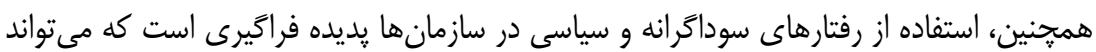
آثار منفى بسيارى از جمله كارزدگى و بدبينى براى سازمان و كاركنان داشته باشد و خون توسط

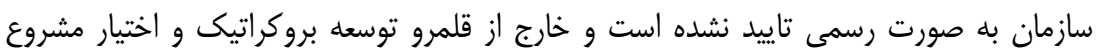

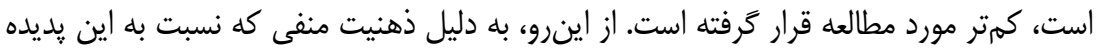

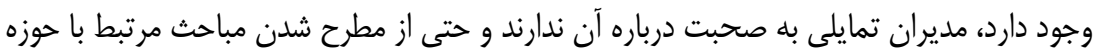




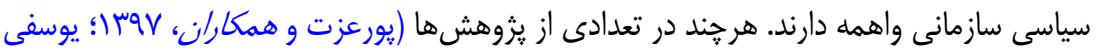

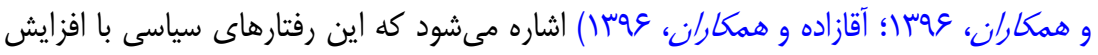

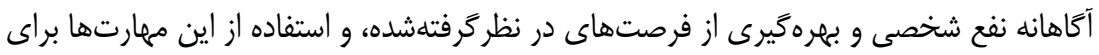

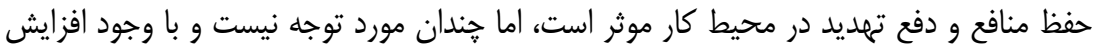

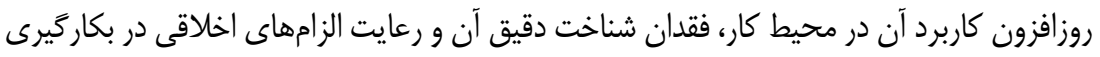

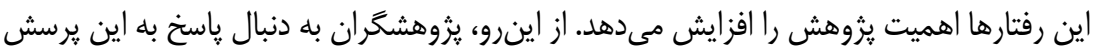

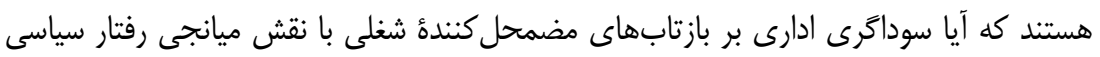

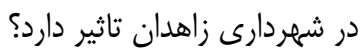

مبانى نظرى يزووهش

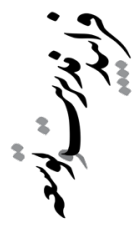

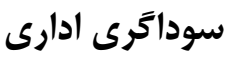

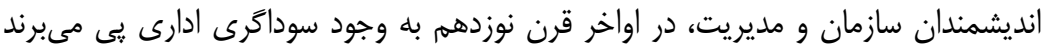

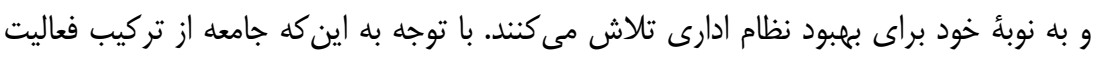

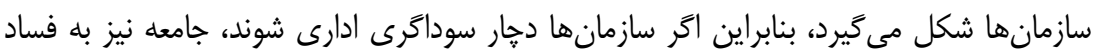

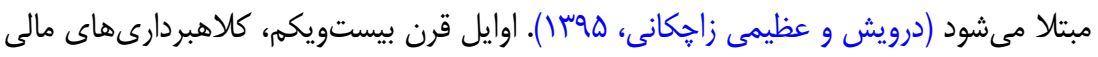

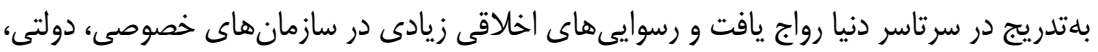

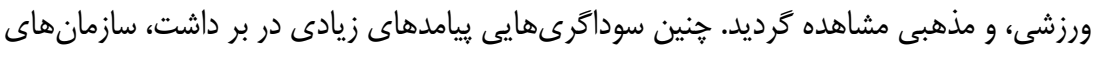

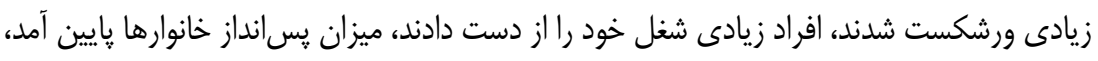

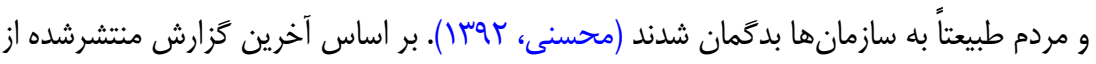

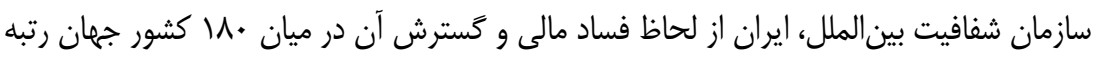

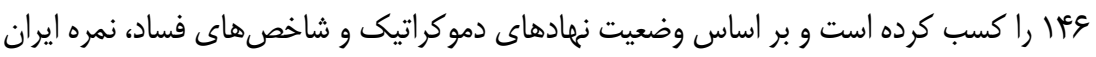

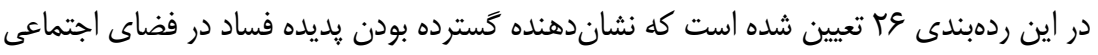

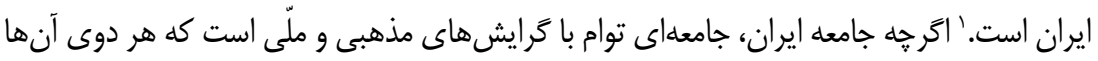

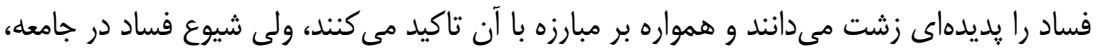

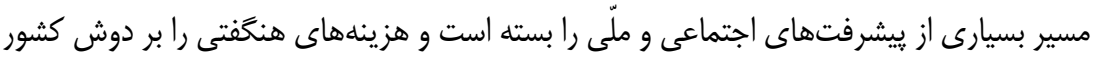

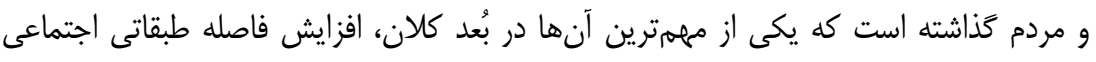


بين غنى و فقير است (يورعزت و همكاران، لوج"). يس سوداگرى ادارى عبارت است از نوعى

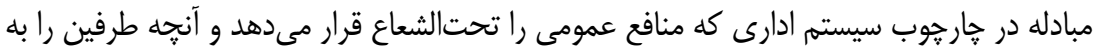

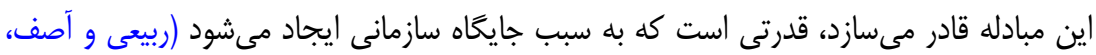

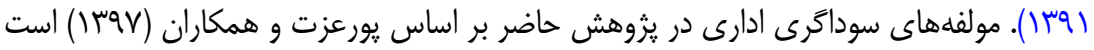
كه شامل الف. سوداگرى براى كسب سِمت: صاحبمنصبانى كه براى رسيدن به قدرت، از نفوذ و

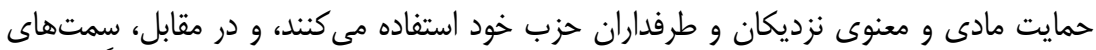
ادارى را به حاميان اصلى حزب اعطا مى كنند و بدين ترتيب، سراسر دستخاه ادارى را از وابستخان حزبى يا نسبى خود انباشته مىسازند؛ ب. سوداگرى در فرايندهاى كار: رفتارهايى است كه با نقض قوانين كارى، سازمان را تهديد مى كند و اين موضوع، هميشه مورد توجه يزوهشكگران سازمان بوده

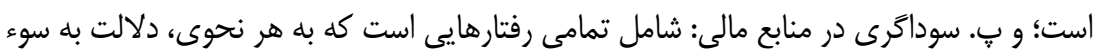
استفاده فرد از منابع مالى سازمان دارد.

\section{باز تابهاى مضمحل كنندهُ شغلى}

در قرن سوم در دوران فساد اخلاقى رم باستان بازتابهاى مضمحل كننده شغلى به عنوان مكتب

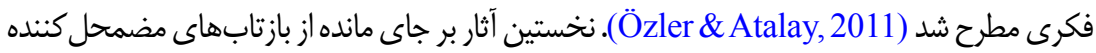
شغلى مربوط به كاركران آمريكايى است كه آن را در قالب نكرش هایى منفى و بىاعتقادى به مراجع

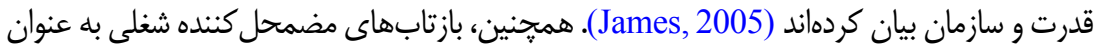
نخرشى منفى نسبت به سازمان مطرح است و دربر يريرندة اين اعتقاد است كه سازمان غيرقابل اعتماد

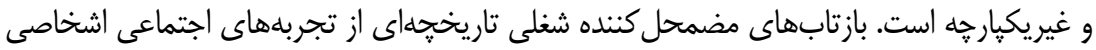

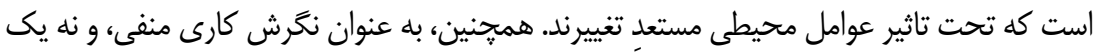

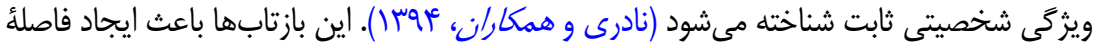
روانى بين كاركنان و سازمان مىشود و اثر مخربى بر كار ايى سازمان و رضايت شغلى كاركنان دارد.

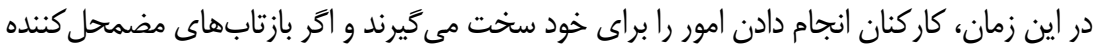

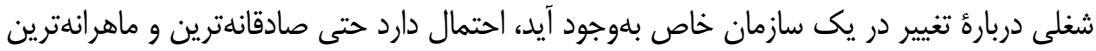
تلاشها براى تغيير مثبت سازمانى به وسيلئ شيوع بازتابهاى مضمحل كننده شغلى ممانعت شود (Arabaci, 2010). موذن جمشيدى و حقيرست كنارسرى (YVIII)، مولفهاى بازتابهاى

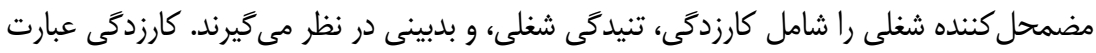

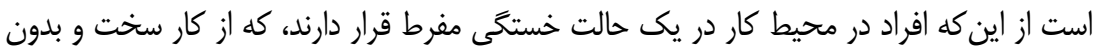


علاقه ناشى مىشود (Borges et al., 2015). تنيدگى شغلى، پاسخهاى فيزيكى و احساسى مضرى

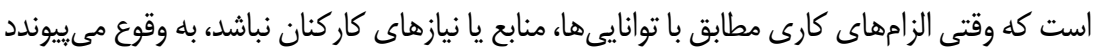

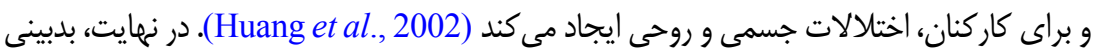
سازمانى عبارت است از نخرش و احساس منفى در كاركنان سازمان و باورى كه سازمان را فاقد

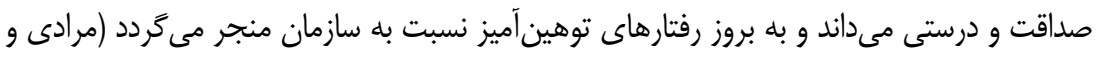

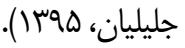

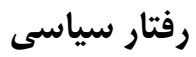

نخستين بار مينتزبرى' (به19)، رفتار سياسى را در توصيف ويزگى هاى فردى ضرورى

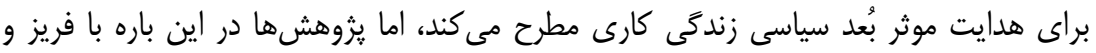

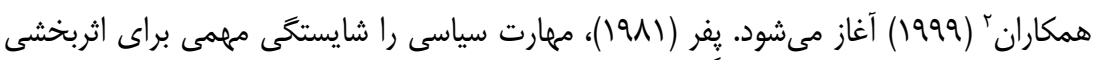

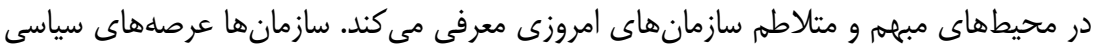

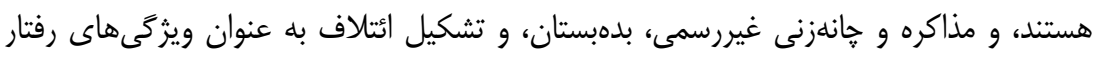

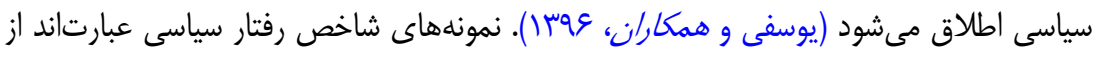

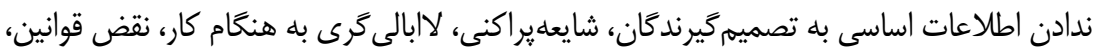

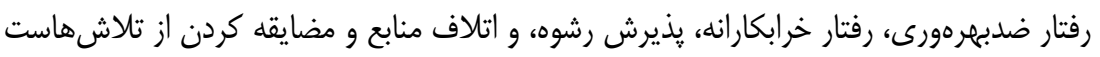

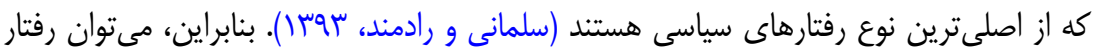

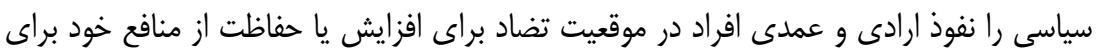

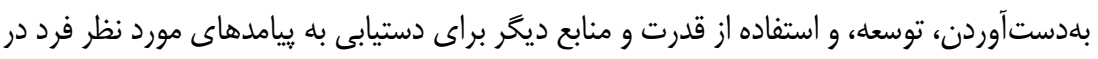

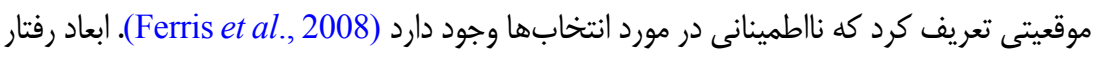

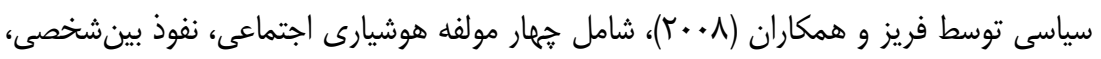

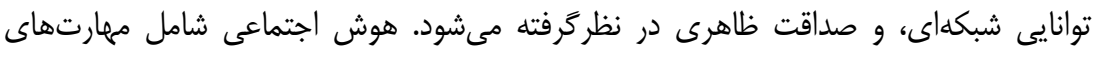

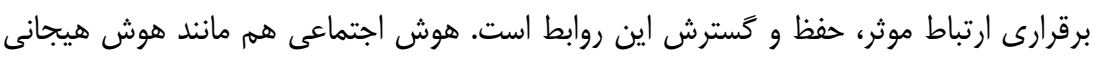

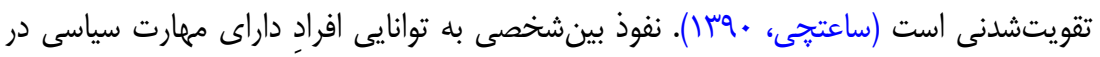

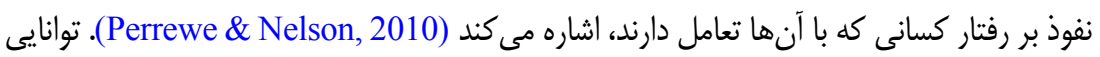

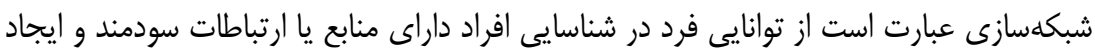

1. Mintzberg

2. Ferris et al. 
شبكههاى اجتماعى با آنها و فراهم كردن سرمائُ اجتماعى و حمايت اجتماعى از اين طريق براى

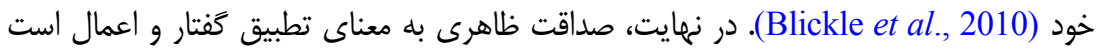
و جنبة مهمى از صداقت است كه به رفتار اجتماعى توجه دارد (Ban Iddekinge et al., 2005).

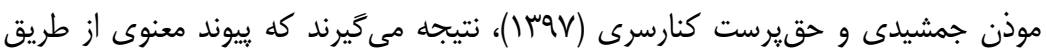

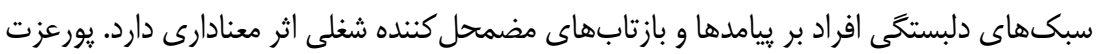

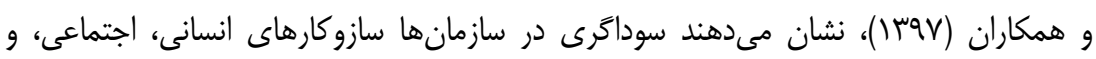

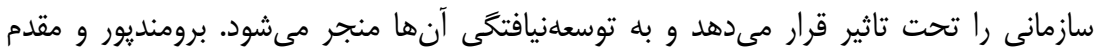

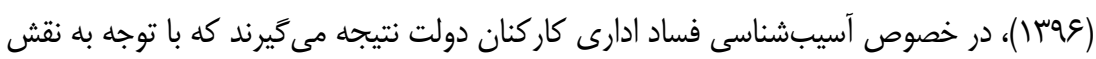

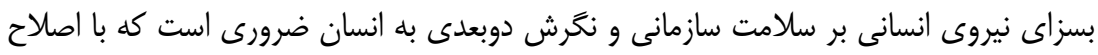

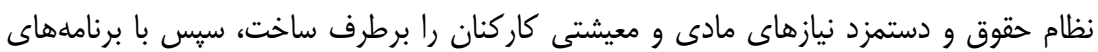

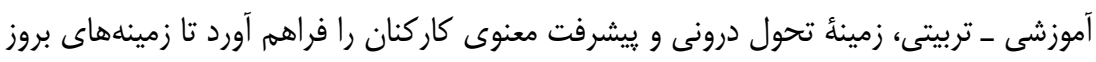

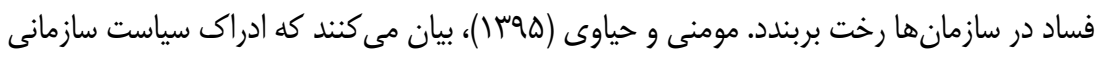
با استرس شغلى، قصد ترك شغل، و بدبينى به سازمان رابطه دارد. به عالاوه، بدبينى به سازمان

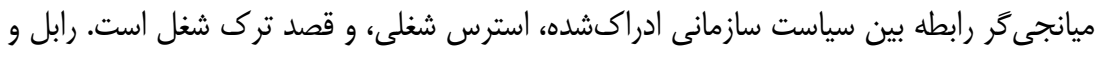

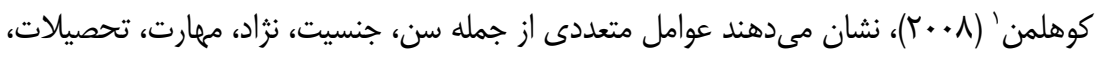

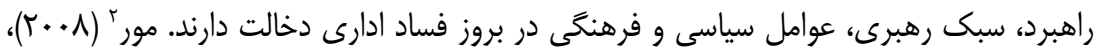

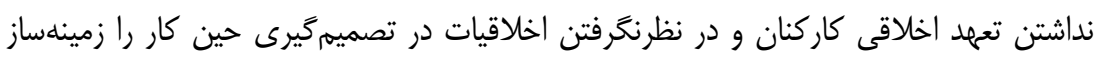

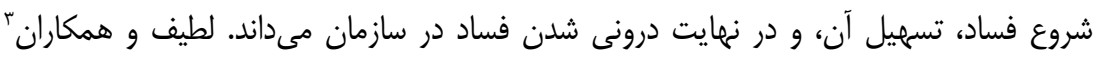

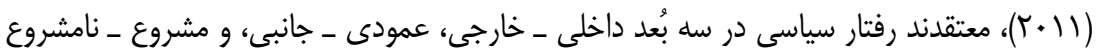

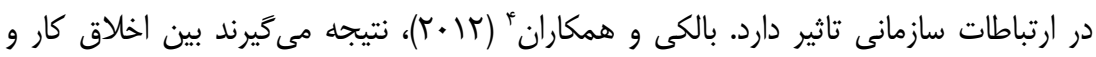

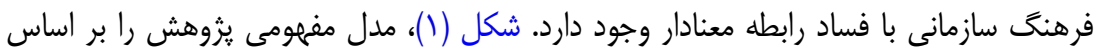

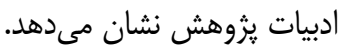

1. Rabl \& Kühlmann

2. Moore

3. Latif et al.

4. Balc1 


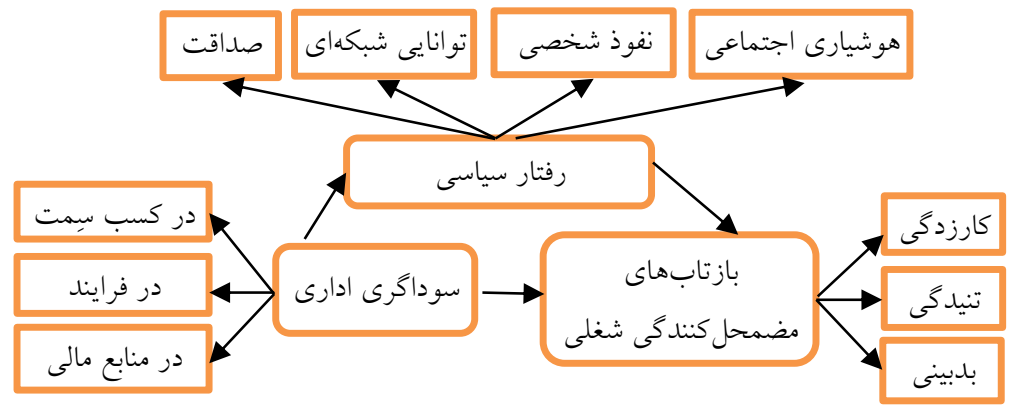

شكل 1: مدل مفهومى بثووه

در نهايت، بر اساس مبانى نظرى و تجربى يزوهش فرضيdهاى يزوهش به اين شرح است: H مولفههاى سوداگرى ادارى بر بازتابهاى مضمحل كننده شغلى در كاركنان شهردارى

$$
\text { زاهدان اثر مثبت دارد. }
$$

: مولفههاى رفتار سياسى بر بازتابهاى مضمحل كننده شغلى در شهردارى زاهدان اثر

$$
\text { مثبت دارد. }
$$

: مولفههاى سوداگرى ادارى بر رفتارهاى سياسى كاركنان شهردارى زاهدان اثر مثبت دارد. H4 : رفتار سياسى در كاركنان به شكل مثبتى در رابطه بين سوداگرى ادارى و بازتابهاى

مضمحل كننده شغلى نقش ميانجى دارد.

\section{روش}

يزوهش حاضر از حيث هدف كاربردى، از نظر اجرا توصيفى از نوع همبستخى و مبتنى بر مدلسازى

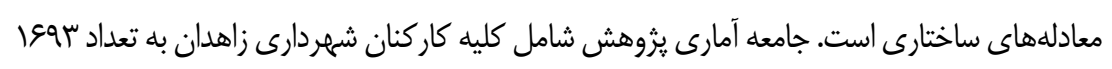

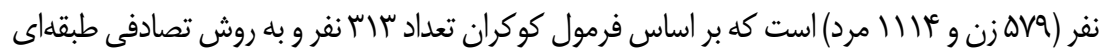

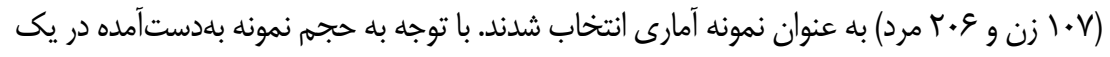

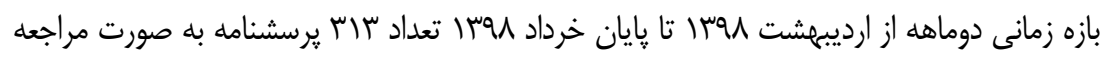

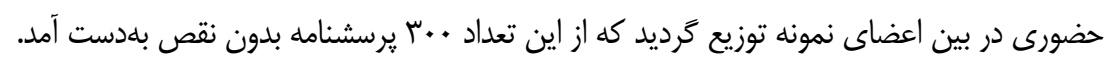
نياز به اشاره است در مرحله توزيع يرسشنامهها براى جلوكيرى از سوگيرى روش مشترك، يرسشنامهها در ميان كاركنان ييمانى و رسمى شاغل در شهردارى زاهدان توزيع گرديد تانمونه مورد بررسى نماينده كل افراد جامعه مورد نظر باشد. همجنين، انتخاب اعضاى نمونه به صورت كاملاً تصادفى صورت يذيرفت. به منظور گردآورى اطلاعات از روش كتابخانهاى شامل (كتب و نشريههاى خارجى و داخلى، 
يايخاههاى داده، و سايتهاى اينترنتى) و ميدانى (يرسشنامه) استفاده گرديد. براى سنجش متغيرهاى

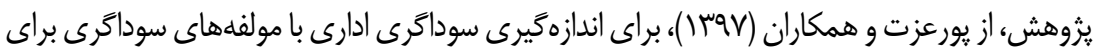
كسب سمت، سوداكرى در فرايندهاى كار، و سوداكرى در منابع مالى؛ از موذن جمشيدى و حقيرست

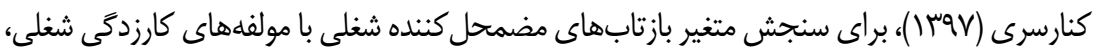

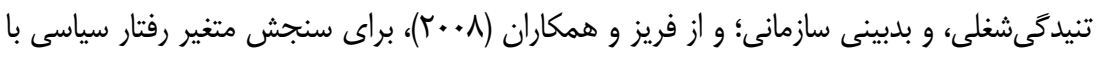
مولفههاى هوشيارى اجتماعى، نفوذ بينشخصى، توانايى شبكهاى، و صداقت استفاده كَرديد. براى

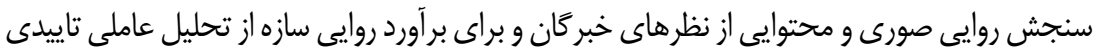

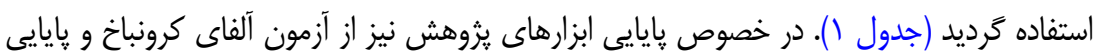

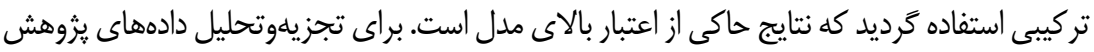
از نرمافزارهاى SPSS23 و SPLart PLS 3 و روش مدلسازى معادلههاى ساختارى استفاده كرديد.

جدول ا: شاخصهاى ارزيابى اعتبار و ثايايى برسشنامهاى ثخوهش

\begin{tabular}{|c|c|c|c|c|c|c|c|c|}
\hline \multicolumn{2}{|c|}{ هيايايى } & \multirow{2}{*}{ فورنبار واكرا } & \multirow{2}{*}{ اعتبار همخرا } & \multirow{2}{*}{ ضرايب } & \multirow{2}{*}{ عارماى } & \multirow{2}{*}{\multicolumn{2}{|c|}{ مولفهها }} & \multirow[b]{2}{*}{ متغير } \\
\hline تر يايايى & كرونباخ & & & & & & & \\
\hline \multirow{2}{*}{$\cdot / N 1$} & \multirow{2}{*}{$\cdot N Q$} & \multirow{2}{*}{$\cdot / M$} & \multirow{2}{*}{$\cdot / \mathrm{Vq}$} & $1 \Lambda / \Lambda F$ & $\cdot / \wedge 9$ & k1 & سوداكرى در & \multirow{14}{*}{$\begin{array}{c}\frac{3}{2} \\
\frac{1}{\sqrt{3}} \\
\frac{y}{3} \\
\frac{3}{3}\end{array}$} \\
\hline & & & & $\mathrm{V} / \Lambda$. & $\cdot / \Lambda \mid$ & $\mathrm{k} 2$ & كسب سِمت & \\
\hline \multirow{5}{*}{$\cdot / \mathrm{VV}$} & \multirow{5}{*}{ •/AK } & \multirow{5}{*}{.$/ 9$} & \multirow{5}{*}{$\cdot / \wedge 1$} & $\mathrm{IV} / \cdot \mathrm{I}$ & $\cdot / \mathrm{V} V$ & k3 & \multirow{5}{*}{ سوداكرى در } & \\
\hline & & & & $9 / 99$ & .190 & $\mathrm{k} 4$ & & \\
\hline & & & & $Y / r q$ & .199 & k5 & & \\
\hline & & & & $Q / \Delta V$ & $\cdot / \Delta \Lambda$ & k6 & & \\
\hline & & & & $r r / v \cdot$ & $\cdot / \wedge 1$ & $\mathrm{k} 7$ & & \\
\hline \multirow{7}{*}{$\cdot|\wedge|$} & \multirow{7}{*}{$\cdot N Y^{4}$} & \multirow{7}{*}{$\cdot / 199$} & \multirow{7}{*}{$\cdot / \wedge$} & $19 / 1$. & $\cdot / \mathrm{VV}$ & $\mathrm{k} 8$ & \multirow{7}{*}{ سوداكرى در مالى } & \\
\hline & & & & $T Y / D Q$ & •/A & k9 & & \\
\hline & & & & $T / M V$ & תז/. & $\mathrm{k} 10$ & & \\
\hline & & & & $V / V I$ & .194 & $\mathrm{k} 11$ & & \\
\hline & & & & $r / q$. & $\cdot / 1$ & $\mathrm{k} 12$ & & \\
\hline & & & & $r / \cdot \wedge$ & $\cdot / 4 q$ & k13 & & \\
\hline & & & & $11 / \mathrm{VQ}$ & .199 & $\mathrm{k} 14$ & & \\
\hline
\end{tabular}

1. Fornell \& Larcker 
ادامه جدول 1: شاخصهاى ارزيابى اعتبار و پايايى يرسشنامهاى بزوهش

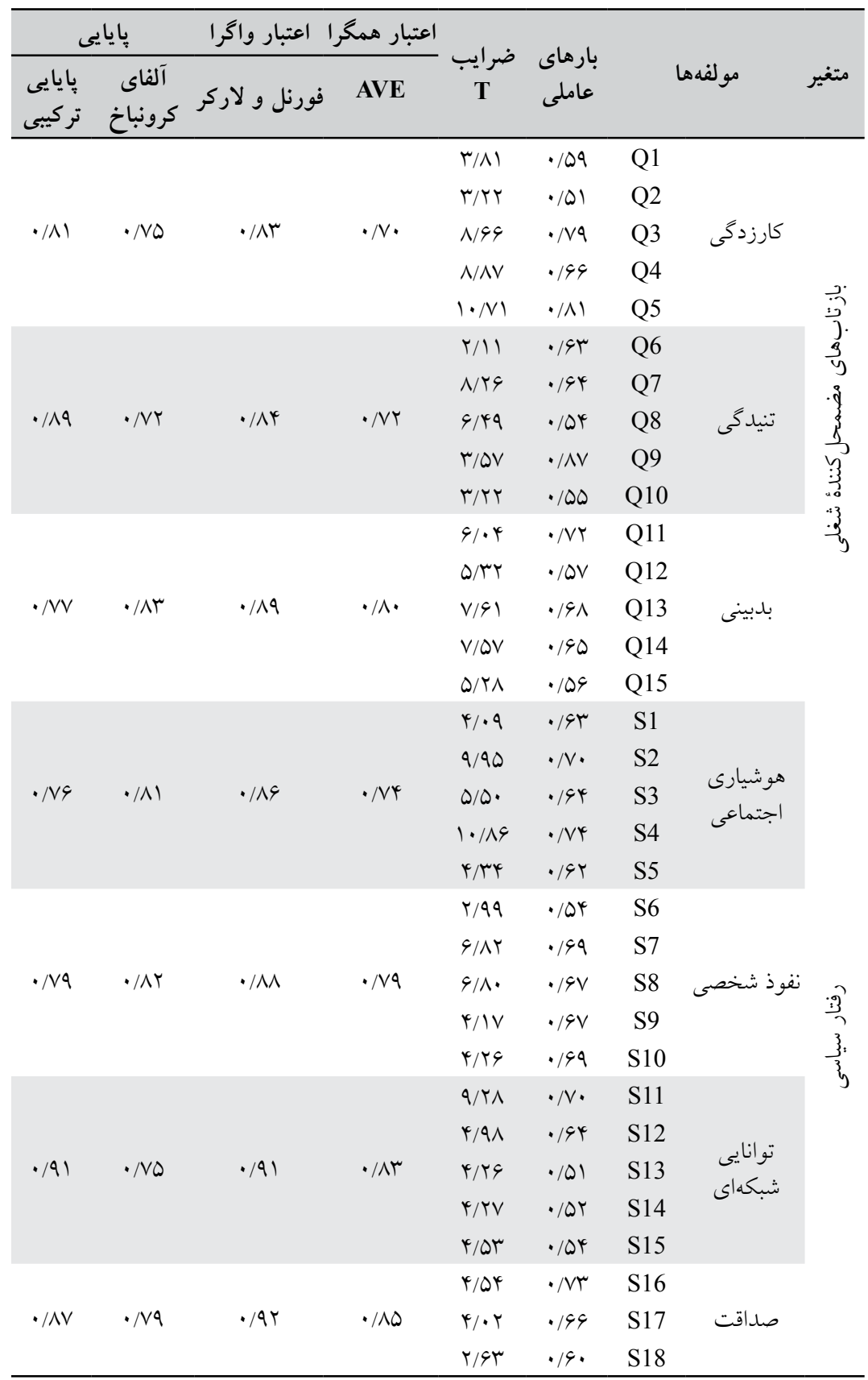

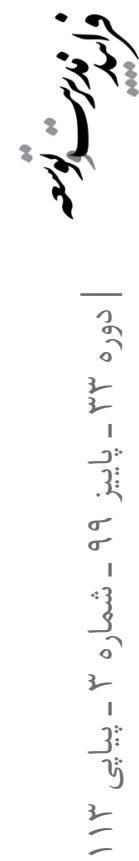


با توجه به اين كه شاخص AVE به بررسى روايى همخرا و ميزان همبستخى هر سازه با سنجههاى

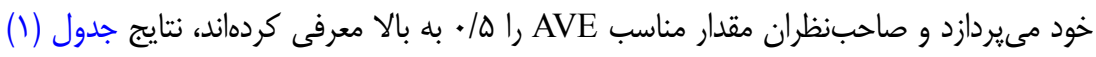

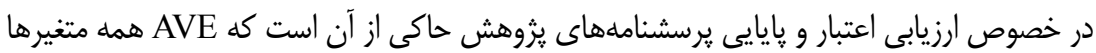
و شاخصها در خصوص يرسشنامهاى سوداگرى ادارى، بازتابهاى مضمحل كننده شغلى، و رفتار

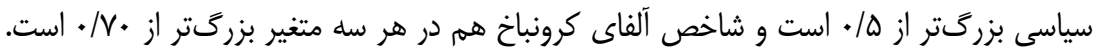

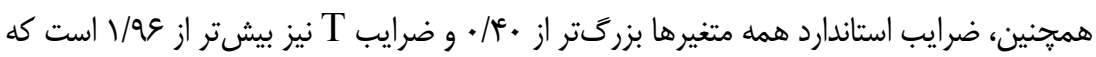
حاكى از اعتبار مناسب يرسشنامههاى يزوهش است.

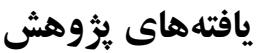

براى بررسى فرضيهها از رويكرد مدلسازى معادلهاى ساختارى واريانسمحور به دليل غيرنرمال بودن دادهاى بروهش استفاده مى بود. در مدل مستقيه، اثر متغيرهاى سوداكرى ادارى و رفتار سياسى بر بازتابهاى مضمحل كننده شغلى سنجيده مى شود. در مدل غيرمستقيم نيز رفتار سياسى در نقش ميانجى بين متغيرهاى سوداكرى ادارى و بازتابهاى مضمحل كننده شغلى ظاهر مىشود. جدول (T)، كزارش مشروح نتيجأ فرضيهها را نمايش مى دهد.

جدول r: نتايج آزمون فرضيهها

\begin{tabular}{|c|c|c|c|c|}
\hline معنادارى & ضريب & متغير وابسته & & فرضيهها \\
\hline 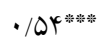 & $\cdot / 9 V$ & باز تابهاى مضمحل كننده شغلى & سوداگرى ادارى & $\mathrm{H}_{1}$ \\
\hline$\cdot / T Q^{* * *}$ & & & سوداگرى براى كسب سِمت & \\
\hline$\cdot / 4 Q^{* *}$ & & & سوداگرى در فرآيندهاى كار & \\
\hline$\cdot / 4 x^{*}$ & & & سوداگرى در منابع مالى & \\
\hline$\cdot / \mu^{*}$ & $\cdot / k^{4}$ & بازتابهاى مضمحل كنتده شغلى & رفتار سياسى & $\mathrm{H}_{2}$ \\
\hline$\cdot /$ & & & هوش اجتماعى & \\
\hline$\cdot / 19^{* *}$ & & & نقوذ بينشخصى & \\
\hline$\cdot / \tau \cdot *$ & & & توانايى شبكهاى & \\
\hline$\cdot / 4 k=$ & & & صداقت ظاهرى & \\
\hline$\cdot / \Delta V^{* * *}$ & - Ma & رفتار سياسى & سوداگرى ادارى & $\mathrm{H}_{3}$ \\
\hline$\cdot / Y^{9^{*}}$ & & & سوداگرى براى كسب يست & \\
\hline$\cdot / Y^{*}$ & & & سوداكرى در فرآيندهاى كار & \\
\hline$\cdot / \mu^{2}$ & & & سوداكرى در منابع مالى & \\
\hline$\cdot / Y^{*}$ &.$/ 19$ & بازتابهاى مضمحل كننده شغلى & سوداگرى ادارى ــ رفتار سياسى & $\mathrm{H}_{4}$ \\
\hline
\end{tabular}

نكته: 
با توجه به نتايج جدول (T)، سوداگرى ادارى بر بازتابهاى مضمحل كننده شغلى (فرضيه H

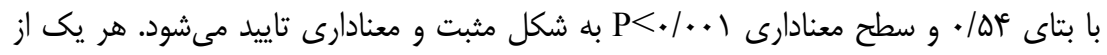

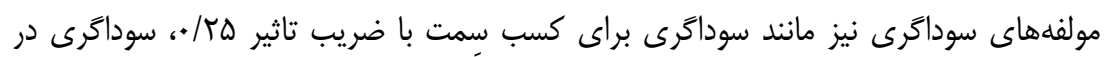

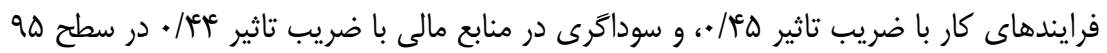

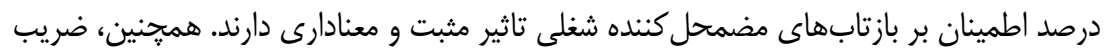

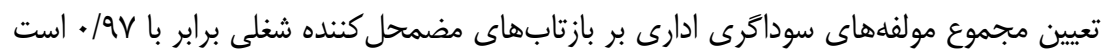

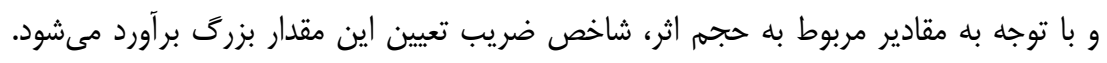

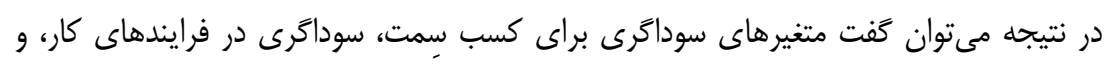

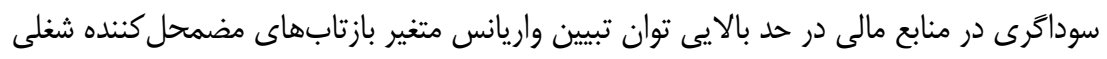

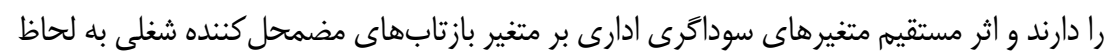
آمارى مثبت و معنادار است. اثر مثبت و معنادار رفتار سياسى بر بازتابهاى مضمحل كننده شغلى (فرضيه

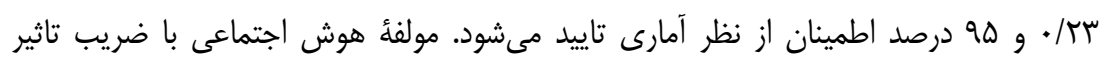

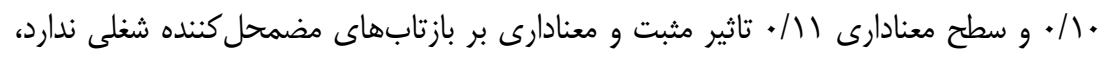

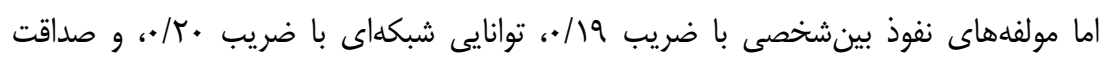

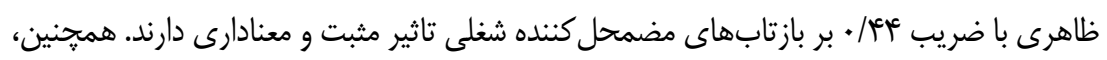

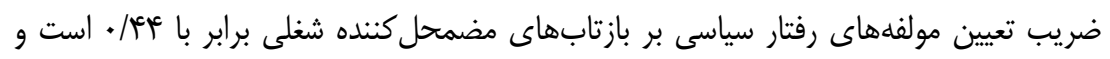

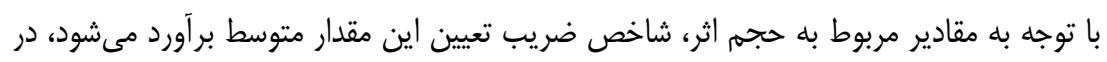

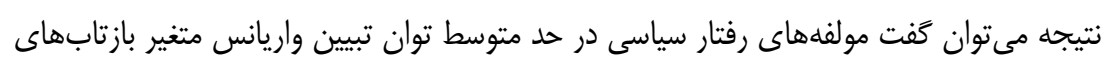
مضمحل كننده شغلى را دارند.

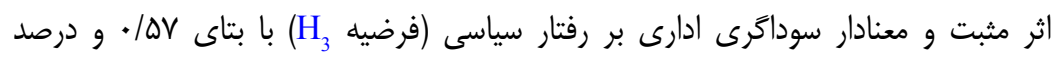

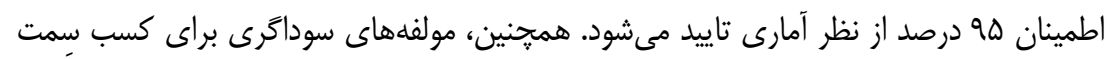

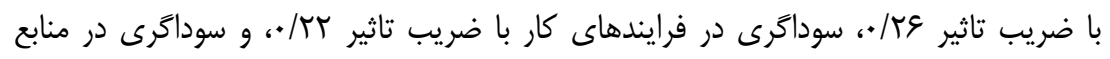

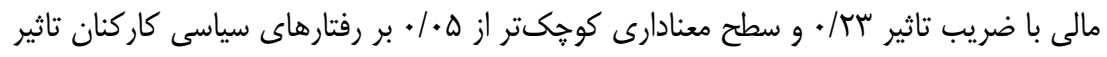

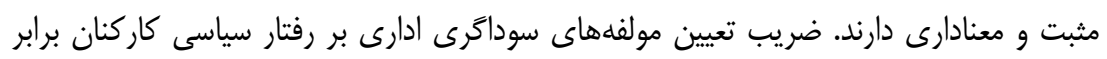

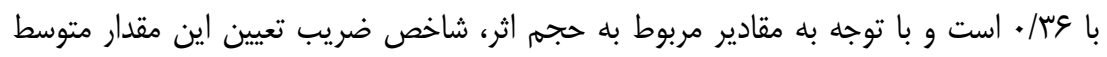
برآورد مى شود. فرضيه 
مضمحل كننده شغلى با بتاى كس// و درصد اطمينان 99 درصد از نظر آمارى تاييد مى كند.

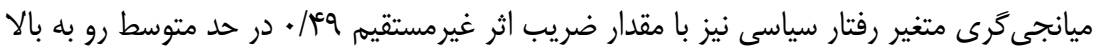
برآورد مىشود.

\section{بحث و نتيجه كيرى}

يثوهش حاضر با هدف بررسى تاثير سوداكرى ادارى بر بازتابهاى مضمحل كننده شغلى با نقش ميانجى رفتار سياسى كاركنان در شهردارى زاهدان انجام مى كيرد.

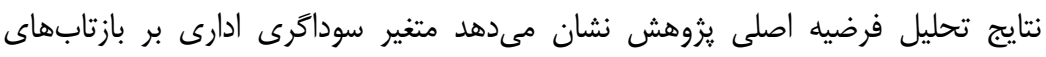

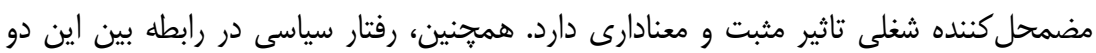

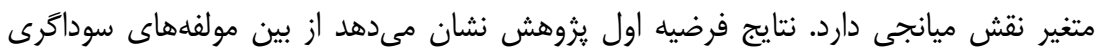
ادارى مولفههاى سوداگرى در فرايندهاى كار و سوداگرى در منابع مالى اثر بيشتر و مولفه

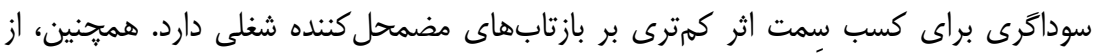

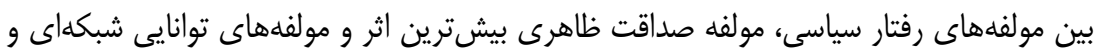
نفوذ بينشخصى در مرتبه هاى بعدى بر باز تابهاى مضمحل كننده شغلى اثر دارند و مولفه هوش

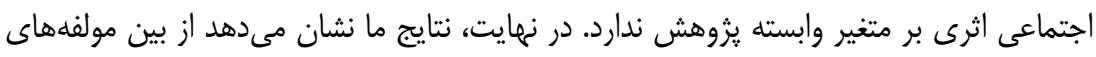

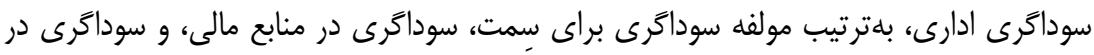

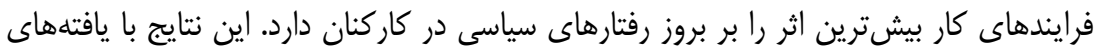

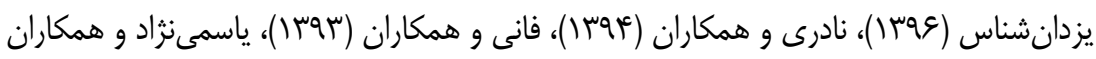

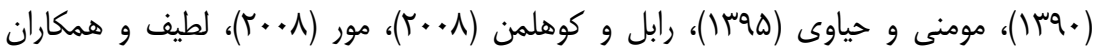

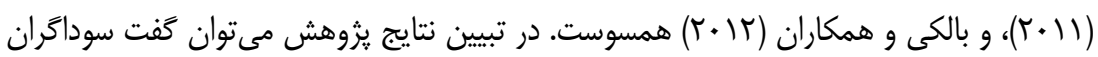

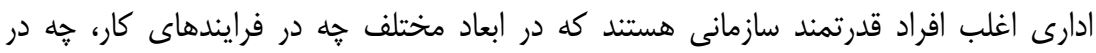

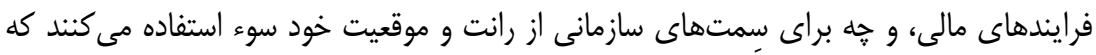

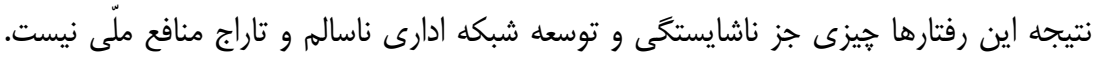

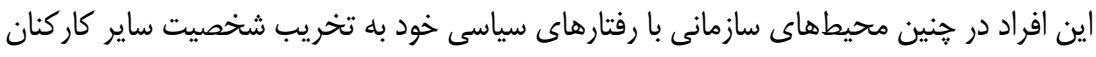

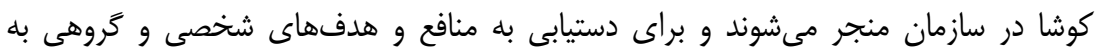
روشهاى غيرمتعارف و غيرمنطقى متوسل مىشوند و با اعمال قدرت و بر اساس ترس و و حذف دانف

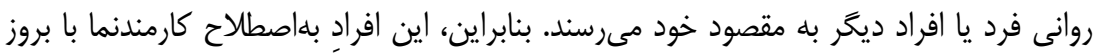

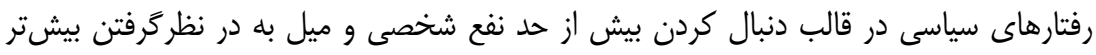


موقعيتها در قالب اصطلاحهاى برد ـ باخت بهجاى اصطاح هاى برد ـ برد، استفاده از تاكتيكهاى

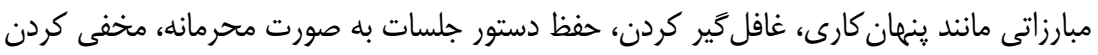

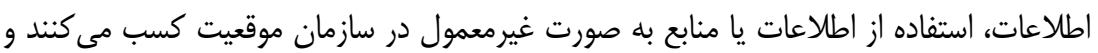

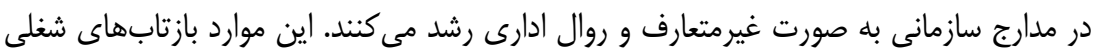

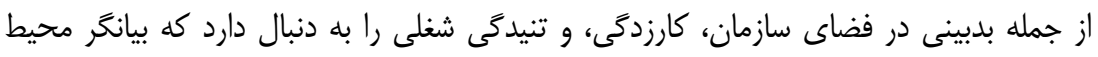

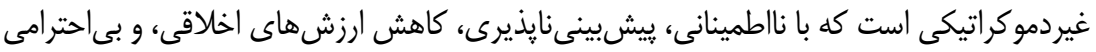

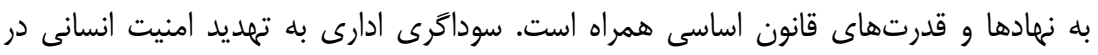

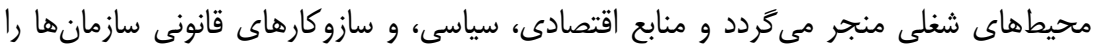

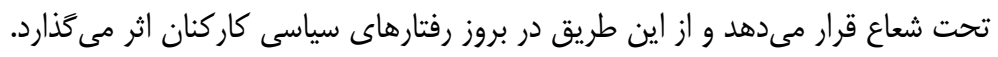

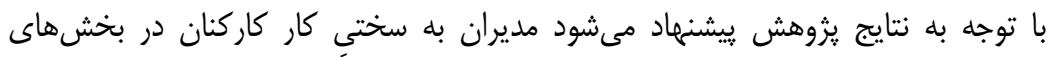
مختلف توجه داشته باشند و از انخيزانندهاى مادى و معنوى مناسب براى جلوكيرى از بران بروز

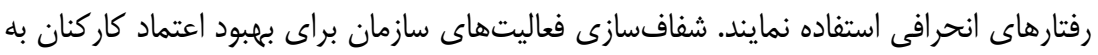

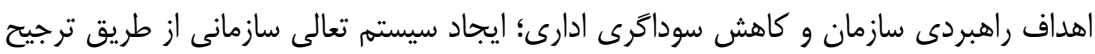

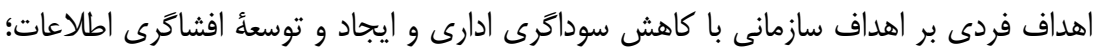

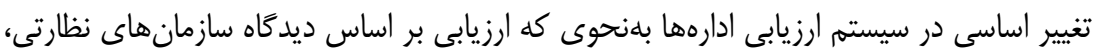

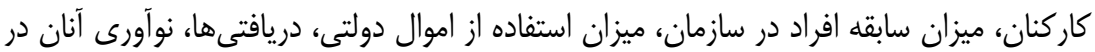

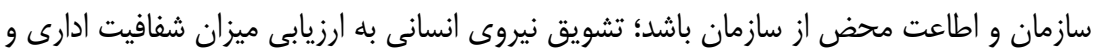

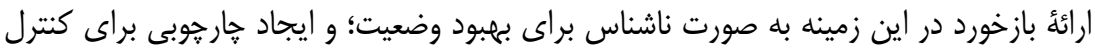

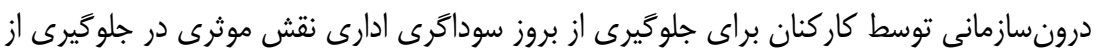

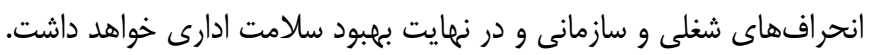

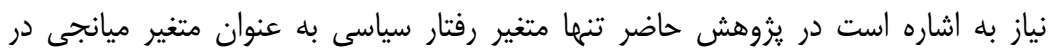
نظركرفته شده است و ساير متغيرهاى مناسب ديخر ممكن است در اين رابطه موثر باشند كه

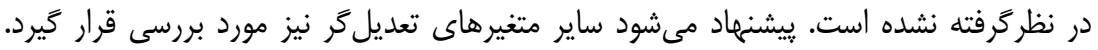

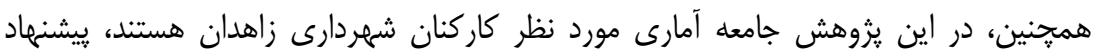
مىشود هنين يزوهشى در ساير سازمانها انجام گردد. در نهايت، با توجه به حساسيت موضوع

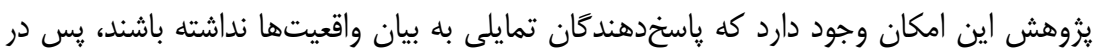
تعميم نتايج بايد احتياط لازم مد نظر قرار كيرد. 


\section{منابع}

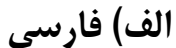

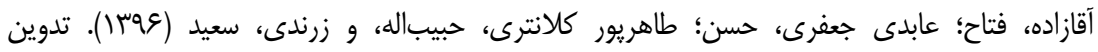

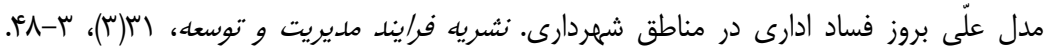
http://jmdp.ir/article-1-3092-fa.html

برومنديور، مهناز، و مقدم، عامر (عوسا). آسيبشناسى فساد ادارى كاركنان دولت. نشريه مطالعات علوم

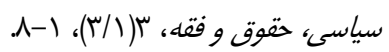

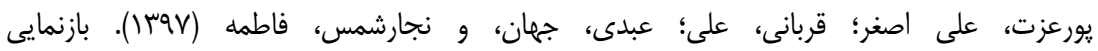

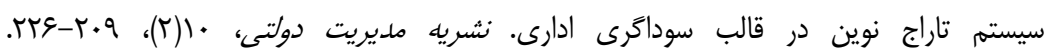
jipa.2018.247808.2150/10.22059

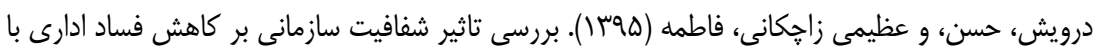

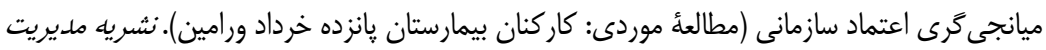

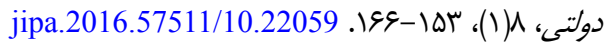

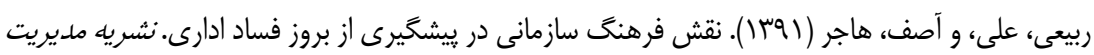

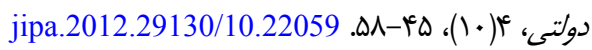

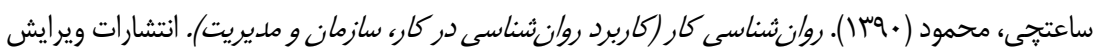

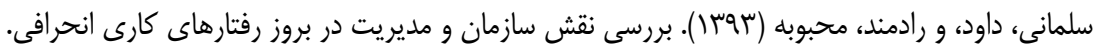

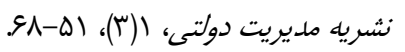

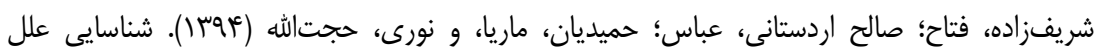

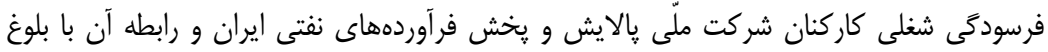

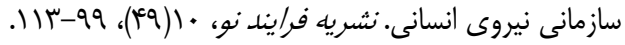

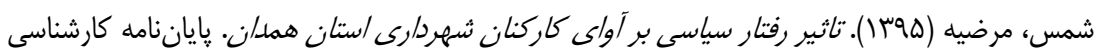

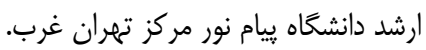

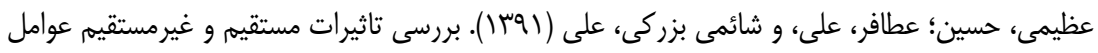

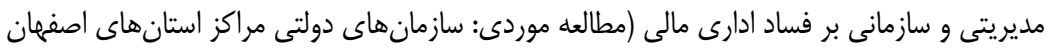

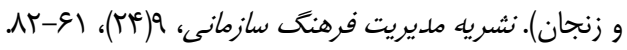

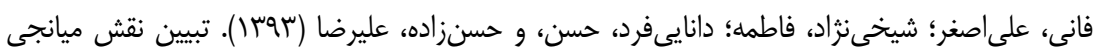

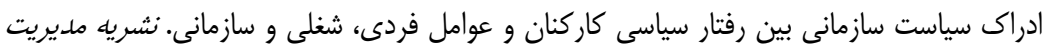

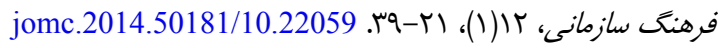

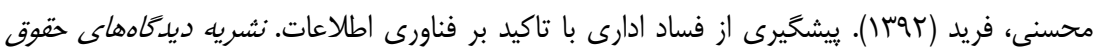

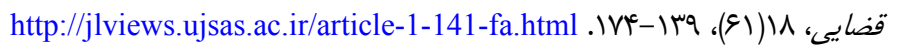

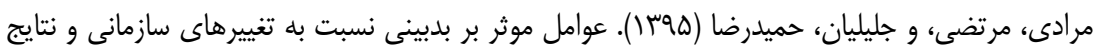

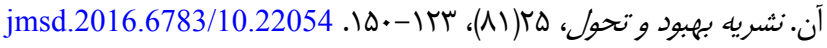


موذن جمشيدى، ميرهادى، و حقيرست كنارسرى، نرجس (1) (1). بررسى تاثير ييوند معنوى بر بازتابهاى

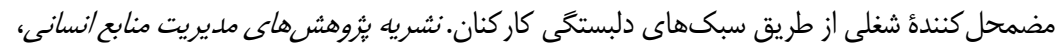
.

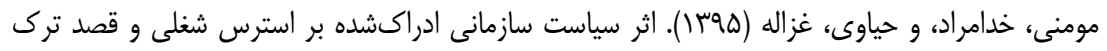

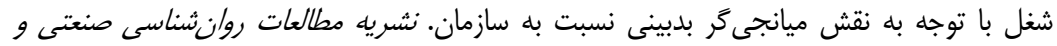

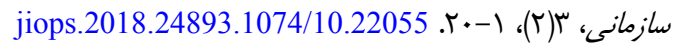

نادرى، جلال؛ جمشيدى، ناصر؛ زارعى متين، حسن (أوجا(). بررسى عوامل سازمانى موثر بر ايجاد بدبينى

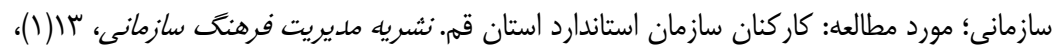
jomc.2015.53298/10.22059.IV\&-IQV

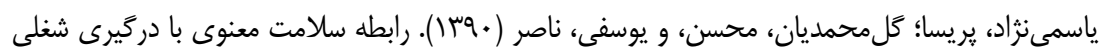

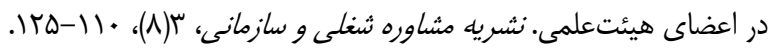

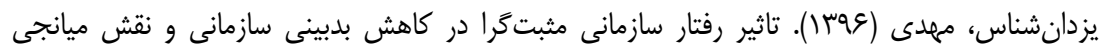

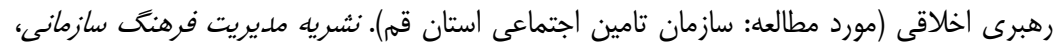

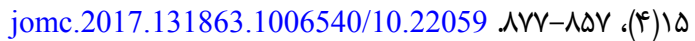

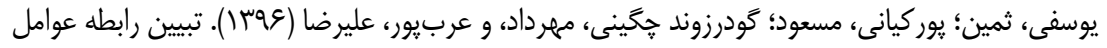

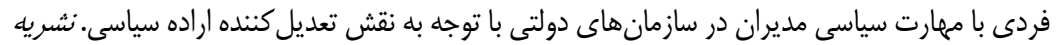

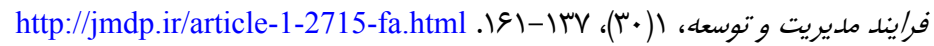

Arabac1, I. B. (2010). The Effects of Depersonalization and Organizational Cynicism Levels on the Job Satisfaction of Educational Inspectors. African Journal of Business Management, 4(13), 2802-2811. https://doi.org/10.5897/AJBM.9000573.

Balcı, A., Özdemir, M., Apaydın, Ç., \& Özen, F. (2012). The Relationship of Organizational Corruption with Organizational Culture, Attitude towards Work and Work Ethics: A Search on Turkish High School Teachers. Asia Pacific Education Review, 13(1), 137-146. https://doi.org/10.1007/s12564-011-9183-8.

Blickle, G., Wendel, S., \& Ferris, G. R. (2010). Political Skill as Moderator of Personality-Job Performance Relationships in Socioanalytic Theory: Test of the Getting Ahead Motive in Automobile Sales. Journal of Vocational Behavior, 76(2), 326-335. https://doi.org/10.1016/j.jvb.2009.10.005.

Borges, M. d. S., Santos, M. B. C., \& Pinheiro, T. G. (2015). Social Representations about Religion and Spirituality. Revista brasileira de enfermagem, 68(4), 609616. https://doi.org/10.1590/0034-7167.2015680406i.

Ferris, G. R., Blickle, G., Schneider, P. B., Kramer, J., Zettler, I., Solga, J., ... Meurs, 
J. A. (2008). Political Skill Construct and Criterion-Related Validation: A Two-Study Investigation. Journal of Managerial Psychology, 23(7), 744-771. https://doi.org/10.1108/02683940810896321.

Ferris, G., Berkson, H., Kaplan, D., Gilmore, D., Buckley, M., Hochwarter, W., \& Witt, L. (1999). Development and Initial Validation of the Political Skill Inventory. Paper Presented at the Academy of Management, 59th Annual National Meeting, Chicago.

Huang, G. D., Feuerstein, M., \& Sauter, S. L. (2002). Occupational Stress and Work-Related Upper Extremity Disorders: Concepts and Models. American Journal of Industrial Medicine, 41(5), 298-314. https://doi.org/10.1002/ajim.10045. James, M. S. (2005). Antecedents and Consequences of Cynicism in Organizations: An Examination of the Potential Positive and Negative Effects on School Systems. (The Degree of Doctor of Philosophy), The Florida State University.

Latif, A., Abideen, Z. U., \& Nazar, M. S. (2011). Individual Political Behavior in Organizational Relationship. Journal of Politics and Law, 4(1), 199-210. Mintzberg, H. (1983). Power in and Around Organizations: Prentice Hall.

Moore, C. (2008). Moral Disengagement in Processes of Organizational Corruption. Journal of Business Ethics, 80(1), 129-139. https://doi.org/10.1007/s10551-007-9447-8.

Özler, D. E., \& Atalay, C. G. (2011). A Research to Determine the Relationship between Organizational Cynicism and Burnout Levels of Employees in Health Sector. Business and Management Review, 1(4), 26-38.

Perrewe, P. L., \& Nelson, D. L. (2004). Gender and Career Success: The Facilitative Role of Political Skill. Organizational Dynamics, 33(4), 366378. https://doi.org/10.1016/j.orgdyn.2004.09.004.

Pfeffer, J. (1981). Power in Organizations: Pitman.

Rabl, T., \& Kühlmann, T. M. (2008). Understanding Corruption in OrganizationsDevelopment and Empirical Assessment of an Action Model. Journal of Business Ethics, 82(2), 477-495. https://doi.org/10.1007/s10551-008-9898-6.

Sowmya, K., \& Panchanatham, N. (2011). Organisational Politics-Behavioural Intention of Bank Employees. The Journal of Commerce, 3(1), 8-21.

Van Iddekinge, C. H., Taylor, M. A., \& Eidson, J., Carl E. (2005). Broad versus NarrowFacets ofIntegrity:Predictive Validity andSubgroupDifferences. Human Performance, 18(2), 151-177. https://doi.org/10.1207/s15327043hup1802_3.

Vinzi, V. E., Chin, W. W., Henseler, J., \& Wang, H. (2010). Handbook of Partial Least Squares (Vol. 201): Springer. 


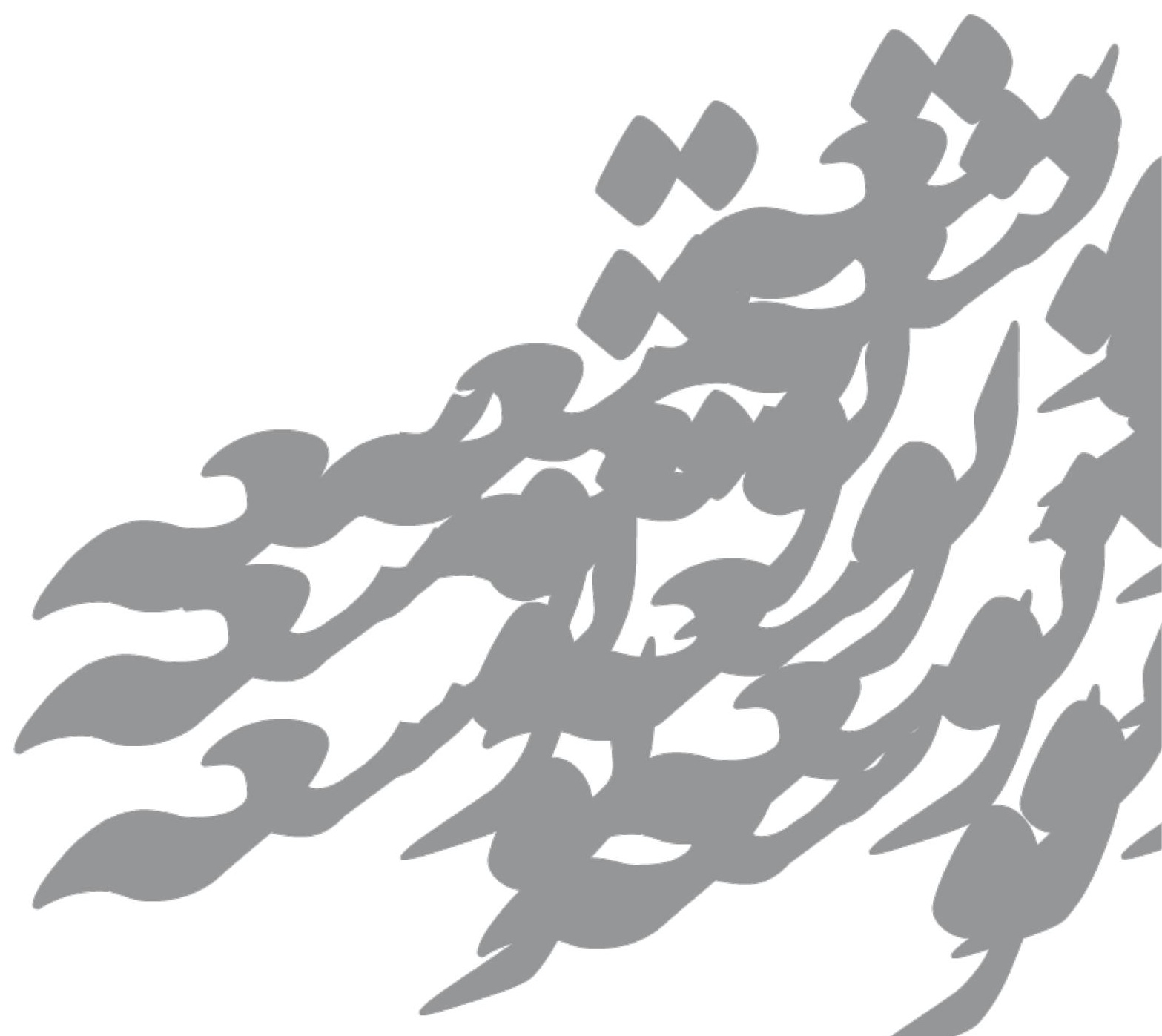

